\title{
Examining the Individual Innovativeness and Online Learning Attitudes of Academic Staff in Institutions Providing Sports Training at the Level of Bachelor Degree
}

\section{Alparslan Muharrem Kurudirek ${ }^{\circledR}$ Irfan Muhammet Kurudirek ${ }^{2}$ (D)}

${ }^{\prime} \mathrm{D} r$, Ataturk University, Faculty of Sports Sciences, Erzurum, Turkey. Email:alparslan1@gmail.comTel: +905335528256

${ }^{2} \mathrm{D} r$, Coruh University, High School of Physical Education and Sports, Artvin, Turkey.

Email:Irfan.kurudirek@gmail.com Tel: +905342343274

\section{Abstract}

The purpose of this study was to examine the individual innovativeness and online learning attitudes of academic staff carrying out duty in institutions providing education at the level of bachelor degree in Turkey. The study was conducted online across Turkey via the correlational survey model between September 2020 and November 2020. The population of the study comprised academic staff carrying out duty in faculties of sports sciences in state universities in Turkey. The sample group consisted of 104 academicians who carry out duty in faculties of sports sciences in state universities chosen randomly from the seven regions in Turkey and agreed to participate in the study. The data of the study were collected using the "Personal Information Form", "Individual Innovativeness Scale (IIS)" and "Online Learning Attitude Scale (OLAS)". The findings of the study showed that the participants obtained medium mean scores from the general acceptance subscale of online learning attitude scale, lower mean scores from the individual awareness subscale, medium mean scores from the perceived usefulness and application effectiveness subscale, and medium mean scores from the overall online learning attitude scale. On the other hand, the individual innovativeness scale mean scores of the participants were evaluated in the innovator category. As a consequence, it was observed that there was a statistically significant, positive, and high correlation between the online learning attitude and individual innovativeness levels of the participants. Accordingly, as the individual innovativeness levels of the participants increased, their online learning attitude levels increased.

Keywords: Individual innovativeness, Online learning attitude physical education and sports, Academic staff.

Citation | Alparslan Muharrem Kurudirek; Irfan Muhammet Kurudirek (2021). Examining the Individual Innovativeness and Online Learning Attitudes of Academic Staff in Institutions Providing Sports Training at the Level of Bachelor Degree. Asian Journal of Education and Training, 7(3): 163-168.

History:

Received: 20 May 202

Revised: 15 June 2021

Accepted: 7 July 2021

Published: 29 July 2021

Licensed: This work is licensed under a Creative Commons

Attribution 3.0 License (c) )

Publisher: Asian Online Journal Publishing Group
Acknowledgement: Both authors contributed to the conception and design of the study.

Funding: This study received no specific financial support.

Competing Interests: The authors declare that they have no conflict of interests.

Transparency: The authors confirm that the manuscript is an honest, accurate, and transparent account of the study was reported; that no vital features of the study have been omitted; and that any discrepancies from the features of the study have been omitted,
study as planned have been explained.

Ethical: This study follows all ethical practices during writing.

\section{Contents}

1. Introduction

References.. 


\section{Contribution of this paper to the literature}

The purpose of this study was to examine the individual innovativeness and online learning attitudes of academic staff carrying out duty in institutions providing education at the level of bachelor degree in Turkey. The study was conducted online across Turkey via the correlational survey model between September 2020 and November 2020.

\section{Introduction}

In a globalising world, the role of information technologies in education has considerably increased. As of 2020, the COVID-19 virus has created the need for a new modelling in education and the concept of online learning has become important for students and teachers to realize effective, continuous and useful educational processes. In parallel with this modelling, individual innovativeness which is among primary concepts having importance in adapting to technological developments, is defined by Yuan and Woodman (2010) as developing, adopting or applying an innovation. The literature has studies suggesting that there is a need for work (following, adapting, developing) to integrate the current one into the relevant area. Ayhan (1999) states that the concept of innovativeness affects the formal education process from preschool until university and is in interaction with lifelong education which comprises the professional experiences of employees and administrators.

It is seen that the internet, which is increasingly used every passing year, also has a significant effect on education life. Especially together with the inclusion of the internet in daily lives; democratisation in access to information, dictionaries, articles and archives, digital private and public libraries, electronic encyclopaedias, digital books, blogs that are presented as web products, discussion forums enabling information exchange, social networks and web pages have become just a click away. This digital transformation radically changes the information access and sharing (Taşkıran, 2017). When evaluating the desire of human beings, who play a major role in the change of the world, to reach the new at individual level, this desire has brought out the concept of individual innovativeness which is an important concept. Individual innovativeness is the individual's application of new and useful opinions by using his/her technical knowledge and experience at the right time on condition that his/her circumstances and all opportunities he/she has obtained are under his/her control. In communities where individual innovativeness has gained importance, the desire of exploring the new, developing the innovation and increasing the competition has also increased instead of the desire of just using the new (Akay \& Gürkan, 2021).

Rogers (2003) summarised basic characteristics related to innovativeness as follows:

- Innovators: Individuals who are willing to try new opinions and take risk and have a vision.

- Early Adopters: Technology-oriented and guiding individuals who inform other individuals in society about innovations.

- Early Majority: Individuals who are cautious against innovations and are not so willing to take risk.

- Late Majority: Individuals who display a sceptical and timid attitude toward innovations.

- Laggards: Individuals who approach change with prejudice and tend to adopt innovations as a final step.

Innovativeness as a process begins with defining the problem, continues with developing suggestions and opinions aimed at the solution of the problem and ends with creating innovations to be prepared for the application. One of the resources of this process is to what extent the individual possesses this characteristic (Yilmaz \& Bayraktar, 2014). Based on all these primary characteristics, it is possible to define an innovative trainer as a person who develops himself/herself in his/her profession, organizes activities in line with his/her curriculum, investigates and examines student-centred new methods, updates his/her behaviours and adapts new capabilities into his/her education life (Ritchhart, 2004). Web-based learning environments like online learning environment are easily accessible systems which offer both users and instructors independence of time and space and solve the capacity problem (Guzley, Avanzino, \& Bor, 2001). Although these systems solve the time and space problems of departments providing theoretical education, it is thought that they do not fully meet the education needs of practice-content departments like sports departments. Technological developments have brought along many positive/negative changes in our way of learning as in our commercial, marketing and shopping habits. In our era, the most important change is experienced in the area of communication. Technological developments manifest primarily in the area of communication and they make their presence felt in society (Güçdemir, 2015).

Considering both in pedagogical and technical terms, the area of online teaching is rapidly changing and developing. Technological developments not only facilitate developing new software and hardware, but also direct researchers to constantly analyse the success of theories and concepts between the media, technology and teaching strategies. However, researchers have a difficulty in extending the concepts concerning what knowledge, skills and attitudes are necessary for the success of online teaching (Watkins, Leigh, \& Triner, 2004).

In Turkey, concepts like open university, online learning, e-learning, distance education, internet education, distance teaching, web-based teaching, internet-based teaching, informal education, flexible learning and virtual education are encountered frequently. Although there are little differences between the concepts, these concepts can be interchangeably used in the universal literature (Ozkul \& Aydin, 2012). Today, online learning processes close to these concepts have begun to be seen in the field of sports sciences. The fact that most state universities include sports sciences departments in their open university and distance education programs stresses the importance of this study. It is because the gradually decreasing physical capacity of physical education and sports department students (Ocak, 2016) indicates the place of the concepts of online learning and application in the field of sports sciences.

\section{Material and Method \\ 2.1. Type of the Study}

This is a correlational survey study.

The study was conducted online across Turkey between September 2020 and November 2020. 


\subsection{Population and Sample of the Study}

The population of the study comprised academic staff working in faculties of sports sciences in state universities in Turkey. The sample group consisted of 104 academicians working in faculties of sports sciences in state universities chosen randomly from the Mediterranean, Eastern Anatolia, Aegean, South-eastern Anatolia, Central Anatolia, Black Sea and Marmara regions in Turkey and were voluntary to participate in the study.

\subsection{Data Collection}

The data were collected in an online environment by the researcher from the people who met the inclusion criteria and were voluntary to participate in the study between September 2020 and November 2020.

\subsection{Data Collection Tools}

The data of the study were collected using the "Personal Information Form", "Individual Innovativeness Scale (IIS)", and "Online Learning Attitude Scale (OLAS)".

\subsubsection{Personal Information Form} title.

It is a 2-question questionnaire prepared by the researcher containing questions related to age and academic

\subsubsection{Individual Innovativeness Scale (IIS)}

The Turkish adaptation of the Individual Innovativeness Scale, which was developed by Hurt, Joseph, and Cook (1977), was conducted by Kılıçer and Odabaşı (2010). The five-point likert scale comprises a total of 20 items. The lowest and highest scores of the scale are 14 and 94, respectively. According to the scores calculated on the basis of the scale, individuals can be categorized in the context of innovativeness. Accordingly, individuals are interpreted to be; "Innovator" if the score is above 80, "Early Adopter" if the score ranges from 69 to 80 , "Early Majority" if the score ranges from 57 to 68, "Late Majority" if the score ranges from 46 to 56 and "Laggard" if the score is below 46. In addition, it is usually possible to make an evaluation concerning the innovativeness level of individuals according to the score calculated with the help of the scale. Accordingly, individuals getting a score above 68 points are evaluated to be highly innovator, while individuals getting a score below 64 points are evaluated to be less innovator. In this study, the Cronbach's alpha coefficient of the scale was found to be .84 .

\subsubsection{Online Learning Attitude Scale (OLAS)}

The scale was developed by Usta, Uysal, and Okur (2016). The 20-item scale is a five-point likert scale with 4 subscales (general acceptance, individual awareness, perceived usefulness and application effectiveness). In this study, the Cronbach's alpha coefficient of the scale was found to be .89 .

\subsubsection{Data Assessment}

The SPSS 26 package program was used to assess the data. After transferring the data which was collected via the data collection tool, in the electronic environment, the normality testing was performed first. Upon detecting that the data were not normally distributed, non-parametric analyses were performed.

\section{Findings}

\begin{tabular}{l|l|c|c}
\multicolumn{3}{c}{ Table-1. Information about Demographic Variables of the Participants. } \\
\hline & & $\mathbf{n}$ & $\%$ \\
\hline \multirow{4}{*}{ Age } & $25-29$ & 8 & 7.7 \\
\cline { 2 - 4 } & $30-34$ & 10 & 9.6 \\
\cline { 2 - 4 } & $35-39$ & 32 & 30.8 \\
\cline { 2 - 4 } & $40-44$ & 24 & 23.1 \\
\cline { 2 - 4 } & $45-49$ & 16 & 15.4 \\
\cline { 2 - 4 } & $50+$ & 14 & 13.5 \\
\hline \multirow{4}{*}{ Title } & Research Assistant & 24 & 23.1 \\
\cline { 2 - 4 } & Lecturer & 28 & 26.9 \\
\cline { 2 - 4 } & Assistant Professor & 22 & 21.2 \\
\cline { 2 - 4 } & Associate Professor & 24 & 23.1 \\
\cline { 2 - 4 } & Professor Dr. & 6 & 5.8 \\
\hline \multirow{4}{*}{ Total } & & 104 & 100 \\
\hline
\end{tabular}

Examining the Table 1, it was observed that most of the participants were aged between 35 and 39 years and were working in the lecturer staff.

Table-2. The Online Learning Attitude Scale and Individual Innovativeness Scale Mean scores of the Participants.

\begin{tabular}{|c|c|c|c|c|c|}
\hline & & $\mathbf{N}$ & Min & $\operatorname{Max}$ & $\mathrm{X} \pm \mathrm{SD}$ \\
\hline \multirow[t]{5}{*}{ Online Learning Attitude } & General Acceptance (GA) & \multirow[t]{5}{*}{104} & \multirow[t]{5}{*}{1} & \multirow[t]{5}{*}{5} & $3.20 \pm .715$ \\
\hline & Individual Awareness (IA) & & & & $2.04 \pm .866$ \\
\hline & Perceived usefulness (PU) & & & & $2.83 \pm 1.226$ \\
\hline & Application Effectiveness (AE) & & & & $2.87 \pm 1.063$ \\
\hline & Online Learning Attitude Scale Total Score & & & & $2.73 \pm 745$ \\
\hline \multicolumn{2}{|l|}{ Individual Innovativeness } & 104 & 14 & 94 & $72.06 \pm 9.324$ \\
\hline
\end{tabular}

When examining the Table 2 , it was observed that the participants' general acceptance subscale mean score of online learning attitude scale was medium, individual awareness subscale mean score was low, mean scores of perceived usefulness and application effectiveness subscales were medium and online learning attitude scale total 
mean scores were medium. On the other hand, the individual innovativeness scale mean scores of the participants were evaluated in the innovator category.

Table-3. Comparison of the online learning attitude scale and individual innovativeness scale mean scores of the participants according to their academic titles.

\begin{tabular}{|c|c|c|c|c|c|c|c|}
\hline Factor & Variable & $\mathbf{N}$ & Mean Rank & sd & $\mathrm{X}^{2}$ & p & Difference \\
\hline General Acceptance & $\begin{array}{l}\text { Research Assistant } \\
\text { Lecturer } \\
\text { Assistant Professor } \\
\text { Associate Professor } \\
\text { Professor Dr. } \\
\end{array}$ & $\begin{array}{c}24 \\
28 \\
22 \\
24 \\
6 \\
\end{array}$ & $\begin{array}{c}66 \\
54.89 \\
49.43 \\
32.27 \\
79.5 \\
\end{array}$ & 4 & 20.981 & .000 & $3<1,4$ \\
\hline Individual Awareness & $\begin{array}{l}\text { Research Assistant } \\
\text { Lecturer } \\
\text { Assistant Professor } \\
\text { Associate Professor } \\
\text { Professor Dr. }\end{array}$ & $\begin{array}{c}24 \\
28 \\
22 \\
24 \\
6\end{array}$ & $\begin{array}{c}74.42 \\
41.96 \\
34.3 \\
48.69 \\
96 \\
\end{array}$ & 4 & 37.578 & .000 & $\begin{array}{l}2<1,5 \\
3<1,5 \\
4<1,5\end{array}$ \\
\hline Perceived usefulness & $\begin{array}{l}\text { Research Assistant } \\
\text { Lecturer } \\
\text { Assistant Professor } \\
\text { Associate Professor } \\
\text { Professor Dr. }\end{array}$ & $\begin{array}{c}24 \\
28 \\
22 \\
24 \\
6\end{array}$ & $\begin{array}{c}68.33 \\
46.79 \\
57.39 \\
32.85 \\
76.5\end{array}$ & 4 & 22.677 & .000 & $4<1,5$ \\
\hline Application Effectiveness & $\begin{array}{l}\text { Research Assistant } \\
\text { Lecturer } \\
\text { Assistant Professor } \\
\text { Associate Professor } \\
\text { Professor Dr. }\end{array}$ & $\begin{array}{c}24 \\
28 \\
22 \\
24 \\
6\end{array}$ & $\begin{array}{c}71.33 \\
40.89 \\
61.64 \\
34.83 \\
68.5\end{array}$ & 4 & 25.719 & .000 & $\begin{array}{c}4<1,3 \\
2<1\end{array}$ \\
\hline $\begin{array}{l}\text { Online Learning Attitude Scale Total } \\
\text { Score }\end{array}$ & $\begin{array}{l}\text { Research Assistant } \\
\text { Lecturer } \\
\text { Assistant Professor } \\
\text { Associate Professor } \\
\text { Professor Dr. }\end{array}$ & $\begin{array}{c}24 \\
28 \\
22 \\
24 \\
6\end{array}$ & $\begin{array}{c}73.44 \\
41.57 \\
51.84 \\
35.17 \\
91.5\end{array}$ & 4 & 11.513 & .000 & $\begin{array}{c}4<1,5 \\
2<1,5 \\
3<5\end{array}$ \\
\hline Individual Innovativeness & $\begin{array}{l}\text { Research Assistant } \\
\text { Lecturer } \\
\text { Assistant Professor } \\
\text { Associate Professor } \\
\text { Professor Dr. }\end{array}$ & $\begin{array}{c}24 \\
28 \\
22 \\
24 \\
6\end{array}$ & $\begin{array}{c}53.79 \\
45.48 \\
42.48 \\
62.58 \\
76.5\end{array}$ & 4 & 33.385 & .021 & $3<5$ \\
\hline
\end{tabular}

When examining the Table 3 , it was observed that there were statistically significant differences between the online learning attitude and subscale mean scores and individual innovativeness scale mean scores of the participants according to their academic titles.

Table-4. Comparison of the online learning attitude scale and individual innovativeness scale mean scores of the participants according to their age groups.

\begin{tabular}{|c|c|c|c|c|c|c|c|}
\hline Factor & Variable & $\mathbf{N}$ & Mean Rank & sd & $\mathbf{X}^{2}$ & p & Difference \\
\hline General Acceptance & $\begin{array}{c}25-29 \\
30-34 \\
35-39 \\
40-44 \\
45-49 \\
50+ \\
\end{array}$ & $\begin{array}{c}8 \\
10 \\
32 \\
24 \\
16 \\
14 \\
\end{array}$ & $\begin{array}{l}54.81 \\
74.95 \\
53.69 \\
55.33 \\
31.53 \\
54.54 \\
\end{array}$ & 5 & 13.704 & .018 & $2>5$ \\
\hline Individual Awareness & $\begin{array}{c}25-29 \\
30-34 \\
35-39 \\
40-44 \\
45-49 \\
50+ \\
\end{array}$ & $\begin{array}{c}8 \\
10 \\
32 \\
24 \\
16 \\
14 \\
\end{array}$ & $\begin{array}{c}70.56 \\
83.25 \\
49.33 \\
38.5 \\
44.16 \\
61 \\
\end{array}$ & 5 & 21.474 & .001 & $2>3,4,5$ \\
\hline Perceived usefulness & $\begin{array}{c}25-29 \\
30-34 \\
35-39 \\
40-44 \\
45-49 \\
50+ \\
\end{array}$ & $\begin{array}{c}8 \\
10 \\
32 \\
24 \\
16 \\
14 \\
\end{array}$ & $\begin{array}{l}82.13 \\
82.45 \\
62.86 \\
30.42 \\
32.75 \\
50.93 \\
\end{array}$ & 5 & 42.043 & .000 & $\begin{array}{l}4<1,2,3 \\
5<1,2,3\end{array}$ \\
\hline Application Effectiveness & $\begin{array}{c}25-29 \\
30-34 \\
35-39 \\
40-44 \\
45-49 \\
50+ \\
\end{array}$ & $\begin{array}{c}8 \\
10 \\
32 \\
24 \\
16 \\
14 \\
\end{array}$ & $\begin{array}{c}74.38 \\
68.85 \\
69.13 \\
34.67 \\
27.03 \\
50 \\
\end{array}$ & 5 & 37.159 & .000 & $\begin{array}{l}4<1,2,3 \\
5<1,2,3\end{array}$ \\
\hline $\begin{array}{l}\text { Online Learning Attitude Scale } \\
\text { Total Score }\end{array}$ & $\begin{array}{c}25-29 \\
30-34 \\
35-39 \\
40-44 \\
45-49 \\
50+ \\
\end{array}$ & $\begin{array}{c}8 \\
10 \\
32 \\
24 \\
16 \\
14 \\
\end{array}$ & $\begin{array}{c}71.75 \\
80.6 \\
61.36 \\
34.75 \\
32.41 \\
54.57 \\
\end{array}$ & 5 & 39.586 & .000 & $\begin{array}{l}4<1,2,3 \\
5<1,2,3\end{array}$ \\
\hline Individual Innovativeness & $\begin{array}{c}25-29 \\
30-34 \\
35-39 \\
40-44 \\
45-49 \\
50+ \\
\end{array}$ & $\begin{array}{c}8 \\
10 \\
32 \\
24 \\
16 \\
14 \\
\end{array}$ & $\begin{array}{c}71.88 \\
44.05 \\
50.27 \\
78 . \\
21.53 \\
44.25 \\
\end{array}$ & 5 & 30.338 & .000 & $\begin{array}{c}4>2,3,5,6 \\
5<1,3\end{array}$ \\
\hline
\end{tabular}


When examining the Table 4, it was observed that there were statistically significant differences between the online learning attitude and subscale mean scores and individual innovativeness scale mean scores of the participants according to their age groups.

\begin{tabular}{|c|c|c|}
\hline & \multicolumn{2}{|c|}{ Online Learning Attitude } \\
\hline & $\mathbf{r}$ & $\mathbf{p}$ \\
\hline Individual Innovativeness & $738^{* *}$ & .000 \\
\hline
\end{tabular}

When examining the Table 5, it was observed that there was a statistically significant, positive and high correlation between the online learning attitude and individual innovativeness level of the participants. Accordingly, as the individual innovativeness level of the participants increased, their online learning attitude level increases.

\section{Discussion}

The level of technological facilities affects the person's motivation. The level and value of the benefit to be obtained from the use of technology may make a contribution as an additional motivation in learning and teaching (Sadeck, Chigona, \& Cronjé, 2020). In this study examining the online learning attitude and individual innovativeness level of academicians in faculties of sports sciences in state universities in Turkey, the following results were obtained. It was observed that the participants' general acceptance subscale mean score of online learning attitude scale was medium, individual awareness subscale mean score was low, mean scores of perceived usefulness and application effectiveness subscales were medium and total mean score of online learning attitude scale was medium. In the study conducted by Krzyszkowska and Mavrommati (2020) with teachers in Norway, they stated that the individual innovativeness level of teachers played a key role in the development of practical knowledge and skills. On the other hand, the individual innovativeness scale mean scores of the participants were evaluated in the innovator category. Accordingly, it can be stated that the results of the present study are compatible with the inference acquired at the end of the study conducted by Lu, Yao, and Yu (2005) suggesting that the acceptance of technology-oriented innovativeness is one of the most important factors in the effective use of technology.

When examining the online learning attitude and individual innovativeness level of the participants according to their academic titles, it was observed that the participants with associate professor title had lower mean ranks compared to the participants with research assistant and professor doctor title, at a statistically significant level. In the online learning attitude individual awareness subscale, it was seen that the participants with research assistant and professor doctor title had higher mean ranks compared to the participants with lecturer, assistant professor, and associate professor title, at a statistically significant level. In the perceived usefulness subscale of online learning attitude scale, the participants with associate professor title had lower mean ranks compared to the participants with research assistant and professor doctor title, at a statistically significant level. In the application effectiveness subscale of online learning attitude scale, the participants with associate professor title had lower mean ranks compared to the participants with research assistant and assistant professor title, at a statistically significant level and the participants with research assistant title had higher mean ranks compared to the participants with lecturer title, at a statistically significant level. When examining the total mean scores of the online learning attitude scale, it was determined that the participants with professor doctor title had higher mean ranks compared to the participants with lecturer, assistant professor and associate professor title and the participants with research assistant title also had higher mean ranks compared to the participants with lecturer and associate professor title, at a statistically significant level. On the other hand, upon examination of the individual innovativeness scale scores of the participants, it was fonud that the participants with professor doctor title had higher mean ranks compared to the participants with assistant professor title, at a statistically significant level.

When the online learning attitude and individual innovativeness level of the participants according to their age groups were analysed, it was found that in the general acceptance subscale of online learning attitude scale, the participants from age range of 30- 34 years had higher mean ranks compared to the participants from age range of $45-49$ years, at a statistically significant level. In the individual awareness subscale of the online learning attitude scale, the participants aged between 30 and 34 years had higher mean ranks compared to the participants from age ranges of 35 and 39 years, 40 and 44 years and 45 to 49 years, at a statistically significant level. In the perceived usefulness and application effectiveness subscales of the online learning attitude scale and in the online learning attitude scale total score, the participants from age ranges of 40 and 44 years and 45 to 49 years had lower mean ranks compared to the participants from age ranges of 25 and 29 years, 30 and 34 years and 35 and 39 years, at a statistically significant level. On the other hand, when examining the individual innovativeness scale scores of the participants, it was observed that the participants from age range of 40 and 44 years had higher mean ranks compared to those from age ranges of 30 and 34 years, 35 and 39 years, 45 and 49 years and 50 years and above, at a statistically significant level and the participants aged 45 to 49 years had lower mean ranks compared to the participants from age ranges of 25 and 29 years and 35 and 39 years, at a statistically significant level.

It was seen that there was a statistically significant, positive and high correlation between the online learning attitude and individual innovativeness level of the participants.

\section{References}

Akay, D., \& Gürkan, G. C. (2021). The effect of ethical leader perception on individual innovation level in health workers. Journal of Organizational Behavior Review, 3(1), 1-18.

Ayhan, A. (1999). Yenilik (Innovation) (pp. 1-30). Kocaeli: Gebze Institude of Technology Publisihing.

Güçdemir, Y. (2015). Sanal ortamda iletişim (Communication in virtual environment). Istanbul: Derin Publishing. 
Guzley, R., Avanzino, S., \& Bor, A. (2001). Simulated computer-mediated/video-interactive distance learning: A test of motivation, interaction satisfaction, delivery, learning \& perceived effectiveness. Journal of Computer-Mediated Communication, 6(3), JCMC633. Available at: 10.1111/j.1083-6101.2001.tbo0122.x.

Hurt, H. T., Joseph, K., \& Cook, C. D. (1977). Scales for the measurement of innovativeness. Human Communication Research, 4(1), 58-65. Available at: $10.1111 /$ j.1468-2958.1977.tb00597.x.

Kılıçer, K., \& Odabaşı, H. (2010). Individual innovativeness scale (IS): The study of adaptation to Turkish, validity and reliability. Hacettepe University Journal of Education, 38, 150-164.

Krzyszkowska, K., \& Mavrommati, M. (2020). Applying the community of inquiry e learning model to improve the learning design of an online course for in service teachers in Norway. Electronic Journal of e-Learning, 18(6), 462-475. Available at: 10.34190/JEL.18.6.001.

Lu, J., Yao, J. E., \& Yu, C. S. (2005). Personal innovativeness, social influences and adoption of wireless Internet services via mobile technology. The Journal of Strategic Information Systems, 14(3), 245-268. Available at: 10.1016/j.jsis.2005.07.003.

Ocak, Y. (2016). The four-year an investigation of physical and physiological features of students in a physical education and sports department. Eurasian Journal of Educational Research, 65, 217-238. Available at: 10.14689/ejer.2016.65.13.

Ozkul, A. E., \& Aydin, C. H. (2012). Student candidates' views on open and distance learning'. Paper presented at the Academic Informatics Conference 2012, Uşak: Uşak University.

Ritchhart, R. (2004). Creative teaching in the shadow of the standards. Independent School, 63(2), 32-41.

Rogers, E. M. (2003). Diffusion of innovations. New York: A Division of Simon \& Schuster, Inc.

Sadeck, O., Chigona, A., \& Cronjé, J. (2020). Understanding e-learning acceptance among teachers: A grounded-in-theory approach. Electronic Journal of e-Learning, $18(6)$, 575-587. Available at: 10.34190/JEL.18.6.009.

Taşkıran, A. (2017). Higher education in the digital age. Journal of Open Education Applications and Research, 3(1), 96-109.

Usta, İ., Uysal, Ö., \& Okur, M. R. (2016). Online learning attitude scale: development, validity, and reliability. Journal of International Social Research, 9(43), 2215-2222. Available at: 10.17719/jisr.20164317786.

Watkins, R., Leigh, D., \& Triner, D. (2004). Assessing readiness for e-learning. Performance Improvement Quarterly, 17(4), 66-79. Available at: DOI:10.1111/j.1937-8327.2004.tb00321.x.

Yilmaz, O., \& Bayraktar, D. M. (2014). Teachers' attitudes towards the use of educational technologies and their individual innovativeness categories. Procedia-Social and Behavioral Sciences, 116, 3458-3461. Available at: https://doi.org/10.1016/j.sbspro.2014.01.783.

Yuan, F., \& Woodman, R. W. (2010). Innovative behavior in the workplace: The role of performance and image outcome expectations. Academy of Management Journal, 53(2), 323-342. 